\title{
The influence of Combination Therapy Progressive Muscle Relaxation and Deep breathing Relaxation against Stress Levels of diabetics in Prolanis BPJS The Health Of The City Of Palangka Raya
}

\author{
Barto Mansyah ${ }^{1}$, Ns. Syam'ani ${ }^{2 *}$ \\ Diploma Courses III Nursing, Politeknik Kesehatan Palangka Raya, Indonesia \\ *Corresponding Author: \\ Emial: syam ani@yahoo.co.id

\begin{abstract}
.
Diabetes mellitus is one of the diseases with great impact on health and society, not only for its high prevalence but also for chronic complications and high mortality.. The psychological impact of diabetes began to be felt by the patient since he was diagnosed the doctor. Patients begin to experience psychological disorders such stress on himself related to the care and treatment should be undertaken. Conditions of emotional stress that require proper handling in order not to fall on the more severe conditions. This study aims to identify the influence of combination therapy progressive muscle relaxation and deep breathing relaxation against stress levels of patients with diabetes mellitus in Prolanis BPJS Kesehatan Kota Palangka Raya. The design used in this study using the design of the study : "PRE-TEST-POSTTEST DESIGN WITH CONTROL GROUP". In this study population was patients with diabetes mellitus in Prolanis BPJS Kesehatan Kota Palangka Raya. The sampling technique in this study using total sampling technique, as many as 48 people. This research is expected to contribute positively to the management of emotional stress in patients with diabetes mellitus.

Keywords: relaxation therapy, stress levels, diabetes melitus
\end{abstract}

\section{INTRODUCTION}

Diabetes mellitus is one of the diseases with great impact on health and society, not only for its high prevalence but also for chronic complications and high mortality. The prevalence of diabetes mellitus around the world vary greatly. The number of diabetics worldwide is currently estimated to be about 190 million. In the year 2025, this number increased to more than 330 million, with the majority of cases being type 2 diabetes. Type 2 Diabetes is one of the problems of major public health in both developing and developed Countries in the Asia Pacific region. Type 2 Diabetes has been reported in children from Japan, the Pacific Islands, Hong Kong, Singapore, China, Malaysia, Korea and Australia. This has become an epidemic in a number of countries, especially in newly industrialized countries. Incident diabetes mellitus 2 developing countries around the world, maybe because of lifestyle changes, associated with the adoption of western habits is as sedentary, obesity, or diet that is not balanced. (Ashari,2012). The results of Riskesdas 2007 to Central Kalimantan prevalence of Diabetes by $0.9 \%$ of the population are diagnosed with health workers only $0.6 \%$. Palangkaraya with the prevalence of diabetes is $1.4 \%$ of the population diagnosed with diabetes by a health workforce of $1.1 \%$.(The Results Of Riskesdas Kalteng 2007, 2008). While the Data obtained from the Puskesmas Pahandut Palangkaraya found 575 visits of patients with Diabetes Mellitus in the year 2012 and 143 of them experienced complications. (Data On Persons With Diabetes Puskesmas Pahandut Palangkaraya 2012).

The psychological impact of diabetes began to be felt by the patient since he was diagnosed the doctor. Patients begin to experience psychological disorders such stress on himself related to the care and treatment should be undertaken (Tjokroprawiro in Jamaludin 2007). The same thing also expressed Surwit that stress has long been one of the factors which appear in patients with diabetes. When a person faces a situation that cause stress, then the stress response can be either an increase in the hormone adrenaline, which can eventually change the reserves of glycogen in the liver into glucose. High blood glucose levels continuously can lead to diabetes complications. In addition to the factors the length of time suffering from diabetes also includes the factors that can affect the stress levels of diabetes patients (in Jamaludin 2007) it is said that the 
faster a person knowing that he was suffering from diabetes, then the less likely the level of stress because it can still be tolerated with lifestyle changes and has not yet reached the stage of complications.

According to Grant Brecht, as quoted by Renata (2008) that what is meant stress is a disturbance in the body and mind caused by the changes and demands of life, which is influenced by both the environment and the appearance of individuals within that environment. According to Renata (2008) stress can make productivity decreased, pain and disorder-mental disorder emotional. Mental emotional disorder is a condition that indicates the individual is experiencing an emotional changes that can develop into a pathological state if it continues. The symptoms of which contributed a lot to the mental emotional disorder, among others, often suffer from headaches, no appetite, feeling anxious, feeling unhappy, not being able to do something useful in life, daily work distracted and find it difficult to enjoy daily activities, difficulty sleeping, easily frightened, trembling hands, pencernaaan distracted, often crying, difficult decisions, feel worthless and tired easily (Sri 2010). Conditions of emotional stress that require proper handling in order not to fall on the more severe conditions. On the basis of this, the researchers are interested to do research about the effect of combination therapy progressive muscle relaxation and deep breathing relaxation against stress levels of patients with diabetes mellitus in Prolanis BPJS The Health Of The City Of Palangka Raya.

\section{METHODS RESEARCH}

\section{Respondents}

Determination of the sample in pnelitian this is to do a screening to patients with diabetes in Prolanis BPJS Kesehatan Kota Palangka Raya who is experiencing stress (using the instrument DDS) and met the inclusion criteria as follows:
a. Diabetes who is experiencing stress
b. Ages $40-70$ years old
c. Able to communicate well and clearly
d. Able to read and write
e. Willing to become respondents

After screening, we get 27 diabetes who experience stress and meet the inclusion criteria.

\section{Data Analysis}

Data analysis techniques in this study using the test pre-requirements analysis and test of influence. To test the pre-requirements analysis is use a normality test where the test normality of data in this study using statistical non-parametric on the value of Kolmogorov-Smirnov. According to Priyanto (2010) suggests that the data are expressed normal distribution if the significance is greater than 0.05 . While doing the counting test the influence of using the formula pre-test and post-test one group design that is a statistical test using the test dependent sample t-Test (Paired t-Test).

\section{RESULTS AND DISCUSSION}

The results of the research will use the frequency table data overview the level of stress in patients with diabetes mellitus in Prolanis BPJS Kesehatan Kota Palangka Raya by gender, employment status, marital status, and education level.

Table 1. The frequency distribution of the level of stress based on gender

\begin{tabular}{|c|c|c|c|c|c|c|}
\hline \multirow[t]{3}{*}{ Gender } & \multicolumn{4}{|c|}{ Stress Level } & \multirow{2}{*}{\multicolumn{2}{|c|}{ Total }} \\
\hline & \multicolumn{2}{|c|}{$\begin{array}{l}\text { Moderate } \\
\text { Stress }\end{array}$} & \multicolumn{2}{|c|}{$\begin{array}{l}\text { Severe } \\
\text { Stress }\end{array}$} & & \\
\hline & $\mathrm{N}$ & $\%$ & $\mathrm{~N}$ & $\%$ & $\mathrm{~N}$ & $\%$ \\
\hline Male & 6 & 22,2 & 0 & 0 & 6 & 22,2 \\
\hline Women & 19 & 70,4 & 2 & 7,4 & 21 & 77,8 \\
\hline Total & 25 & 92,6 & 2 & 7,4 & 27 & 100 \\
\hline
\end{tabular}

The table above shows the results of the research the number of diabetes who is experiencing stress 
according to gender that is dominated by diabetes sex perermpuan, where the experience of stress is numbered 19 people $(70,4 \%)$ and severe stress amounted to 2 people ( 7.4 percent). And the second is diabetes that male gender, who experience stress are about 6 people $(22,2 \%)$.

1. The frequency distribution of the stress level based on the status of the job

Table 2 frequency Distribution of the stress level based on the status of the job

\begin{tabular}{|l|c|c|c|c|c|c|}
\hline \multirow{2}{*}{ Work } & \multicolumn{3}{|c|}{ Stress Level } & \multicolumn{2}{c|}{ Total } \\
\cline { 2 - 6 } & $\begin{array}{c}\text { Moderate } \\
\text { Stress }\end{array}$ & $\begin{array}{c}\text { Severe } \\
\text { Stress }\end{array}$ & \multicolumn{2}{c|}{} \\
\cline { 2 - 6 } & $\mathrm{N}$ & $\%$ & $\mathrm{~N}$ & $\%$ & $\mathrm{~N}$ & $\%$ \\
\hline Retired & 11 & 40,7 & 0 & 0 & 11 & 40,7 \\
\hline Private & 4 & 14,8 & 2 & 7,4 & 6 & 22,2 \\
\hline Housewife & 10 & 37 & 0 & 0 & 10 & 37 \\
\hline Total & 25 & 92,6 & 2 & 7,4 & 27 & 100 \\
\hline
\end{tabular}

The table above shows the results of the research the number of diabetes that is most subjected to stress according to the status of the job i.e. diabetes retired CIVIL servant with the total number of as many as 11 people (of 40.7\%). And the second is diabetes as a housewife with a total number of 10 people (37\%). And the third is the diabetes working private amounted to 6 people $(22,2 \%)$.

1. The frequency distribution of the level of stress based on marital status

Table 3 frequency distribution of the level of stress based on marital status

\begin{tabular}{|l|c|c|c|c|c|c|}
\hline \multirow{2}{*}{ Marital Status } & \multicolumn{4}{|c|}{ Stress Level } & \multicolumn{2}{|c|}{} \\
\cline { 2 - 6 } & $\begin{array}{c}\text { Moderate } \\
\text { Stress }\end{array}$ & \multicolumn{2}{c|}{$\begin{array}{c}\text { Severe } \\
\text { Stress }\end{array}$} & \multicolumn{2}{c|}{ Total } \\
\cline { 2 - 6 } & $\mathrm{N}$ & $\%$ & $\mathrm{~N}$ & $\%$ & $\mathrm{~N}$ & $\%$ \\
\hline Married & 20 & 74,1 & 2 & 7,4 & 22 & 81,5 \\
\hline Widow/widower & 5 & 18,5 & 0 & 0 & 5 & 18,5 \\
\hline Total & 25 & 92,6 & 2 & 7,4 & 27 & 100 \\
\hline
\end{tabular}

The table above shows the results of the research the number of diabetes who is experiencing stress according to marital status, namely the highest first is diabetes with married status with a total number of 22 people, divided who suffer from stress are numbered 20 people $(74,1 \%)$ and suffering from severe stress amounted to 2 people ( 7.4 percent). As for the second, namely diabetes status widow/widower with a total number of 5 people $(18,5 \%)$ on levels of stress are.

1. The frequency distribution of the stress level based on the level of education

Table 4. frequency distribution of the stress level based on the level of education

\begin{tabular}{|l|c|c|c|c|c|c|}
\hline \multirow{2}{*}{ Education } & \multicolumn{4}{|c|}{ Tingkat Stres } & \multicolumn{2}{|c|}{ Total } \\
\cline { 2 - 6 } & \multicolumn{2}{|c|}{ Stres Sedang } & \multicolumn{2}{|c|}{$\begin{array}{c}\text { Stres } \\
\text { Berat }\end{array}$} & \multicolumn{2}{c|}{} \\
\cline { 2 - 6 } & $\mathrm{N}$ & $\%$ & $\mathrm{~N}$ & $\%$ & $\mathrm{~N}$ & $\%$ \\
\hline $\begin{array}{l}\text { Elementary } \\
\text { School }\end{array}$ & 2 & 7,4 & 0 & 0 & 2 & 7,4 \\
\hline $\begin{array}{l}\text { Junior high } \\
\text { school }\end{array}$ & 4 & 14,8 & 0 & 0 & 4 & 14,8 \\
\hline High School & 10 & 37 & 1 & 3,7 & 11 & 40,7 \\
\hline College & 9 & 33,3 & 1 & 3,7 & 10 & 37 \\
\hline Total & 25 & 92,6 & 2 & 7,4 & 27 & 100 \\
\hline
\end{tabular}

The table above shows the results of the research the number of diabetes who is experiencing stress according to the level of education is the highest first is diabetes that level of education was high School 
with a total of 11 people, consists of: the stress of being numbered 10 people $(37 \%)$ and those who experience severe stress amounts to 1 person ( 3.7 percent). And the second is diabetes that level of education Diploma/S1 with a total number of 10 people, consisting of: who are experiencing the stress of being numbered $9(33,3 \%)$ and who are experiencing severe stress amounts to 1 person (3.7 percent). The third is diabetes with education level of JUNIOR high school consists of 4 people $(14,8 \%)$, and the fourth with a background in ELEMENTARY education amounted to 2 people ( 7.4 percent).

1. The frequency distribution of the level of stress before the intervention

Table 5 frequency Distribution of level of stress before the intervention

\begin{tabular}{|c|c|c|}
\hline Tingkat Stres & N & $\%$ \\
\hline Stres sedang & 25 & 92,6 \\
\hline Stres berat & 2 & 7,4 \\
\hline Total & 27 & 100 \\
\hline
\end{tabular}

The table above shows the results of the study that the level of stress diabetes in Prolanis BPJS Kesehatan Kota Palangka Raya before the intervention, namely the stress of being with an amount of 25 people (yeah, $92.6 \%$ ), and severe stress with the amount of 2 people ( 7.4 percent).

1. The frequency distribution of the level of stress after the intervention

Table 6. frequency Distribution of the level of stress after the intervention

\begin{tabular}{|l|c|c|}
\hline Stress Level & N & $\%$ \\
& & \\
\hline No stress & 9 & 33,3 \\
\hline Stress is & 18 & 66,7 \\
\hline Severe stress & 0 & 0 \\
\hline Total & 27 & 100 \\
\hline
\end{tabular}

The table above shows the results of the study that the level of stress diabetes in Prolanis BPJS Kesehatan Kota Palangka Raya after the intervention i.e. no stress with the number $9(33,3 \%)$, moderate stress with the number of $18(66.7 \%)$ and no more diabetes who experience severe stress.

1. Differences in Stress Levels Before and After Intervention

Table 7. Differences in stress levels before and after intervention in Prolanis

\begin{tabular}{lcccccc}
\hline Variabel & N & Mean & SD & SE & T & p value \\
\hline Stress levels & & & & & & \\
diabetes & 27 & 2,57 & 0,41 & 0,798 & 6,923 & 0,000 \\
& 27 & 2,10 & 0,26 & 0,502 & & \\
\hline a. Before & & 0,47 & & & &
\end{tabular}

The results of the statistical test using the test dependent sample t-Test (Paired t-Test) showed that there are differences in the average level of stress diabetes before and after the intervention, i.e., before the intervention is 2,57 and after the intervention is 2.10 . It shows that the level of stress diabetes after therapy is given progressive muscle relaxation and breath in decreased significantly by 0.47 with $p$ value $=0,000(\alpha$ $0,05)$. Based on the results of a statistical test, it can be concluded that at $\alpha 5 \%$ there were significant differences in the average level of stress diabetes before and after a given intervention in the form of therapy progressive muscle relaxation and deep breathing relaxation ( $\mathrm{p}$ value $0.000<\alpha 0,005$ ).

\section{Discussion}

The results of the statistical test using the test dependent sample t-Test (Paired t-Test) showed that there are differences in the average level of stress diabetes before and after the intervention, i.e., before the 
intervention is 2,57 and after the intervention is 2.10 . It shows that the level of stress diabetes after therapy is given progressive muscle relaxation and breath in decreased significantly by 0.47 with p value $=0,000(\alpha$ $0,05)$. Based on the results of a statistical test, it can be concluded that at $\alpha 5 \%$ there were significant differences in the average level of stress diabetes before and after a given intervention in the form of therapy progressive muscle relaxation and deep breathing relaxation ( $p$ value $0.000<\alpha 0,005$ ). Based on the results of a statistical test, it can be concluded that at $\alpha 5 \%$ there were significant differences in the average level of stress diabetes before and after a given intervention in the form of therapy progressive muscle relaxation and deep breathing relaxation ( $\mathrm{p}$ value $0.000<\alpha 0,005$ ).

The results of this study in accordance with similar studies that have been done by Resti (2014) mentions that the progressive muscle relaxation can also provide psychological effects. After carrying out progressive muscle relaxation the client to be more sedate in thinking and client can manage stress and breathing. Progressive muscle relaxation is a relaxation technique that is easy and simple and already widely used. This procedure get relaxation in the muscles through two steps, namely by providing a voltage on a muscle group, and terminate the voltage is then concentrated attention to how the muscles become relaxed, feel the sensation of relax and tension (Richmond, 2007 in Mashudi, 2011). This opinion is also reinforced by the opinion of Jacobson, which suggests that when anxious, muscles subjected to tension, one can reduce anxiety by learning how to relax muscle tension. Progressive muscle relaxation this requires a physical component and mental (Varvolgi, 2011). Relaxation can also reduce the tension of the subjective and the effect on other physiological processes. Muscle relaxation and deep breathing relaxation goes along with mental relaxation. Feeling anxious subjective can be reduced or eliminated with the suggestion indirect or remove and eliminate components otonomik of that feeling (Resti, 2014).

The results of this study show that after a given combination therapy progressive muscle relaxation and deep breathing relaxation, there is a decrease in the number of diabetes who experience stress, where before the intervention achieved the number of diabetes who is experiencing stress levels are numbered to 25 people (yeah, 92.6\%) and severe stress 2 people (7.4 percent), while after the intervention decreased to $9(33,3 \%)$ no stress, and 18 people $(66,7 \%)$ stress levels are.

Relaxation can only happen when the mind and body in a calm atmosphere, when the rhythm of the brain changes from beta (watch out) to alpha (relaxed). This causes anxiety decreased and blood flow to the muscles decreases, on the contrary the blood flowing to the brain and the skin so as to give a sense of warmth and calm. The technique of progressive muscle relaxation combined with deep breathing relaxation techniques, reduce stress by activating the parasympathetic nervous system and stop the work of the sympathetic nervous system. If the sympathetic system is inhibited then this process will be decreased so that the hormone cortisol decreases, this causes a decrease in the process of gluconeogenesis (formation of glucose), which is actually prepared to enhance the blood glucose levels in a state of stress (as a source of energy to face the state of stress).

A similar thing also we can know from the opinions Domin (2001) in Wulandari (2006) who suggested that the physiological relaxation exercises will reverse the effects of anxiety that involves parts of the parasympathetic of the central nervous system. Workout relaxation therapy will inhibit the increase of nerve sympathetic, so that the hormone causes dysregulation of the body can be reduced in number. The nervous system paraimpatis which has a work function opposite to the sympathetic nerves, it will slow down or weaken the working tools of the internal body. The result is a decrease in the heartbeat, the rhythm of the breath, blood pressure, muscle tension, metabolic rate, and the production of hormones causes of stress. In line with the decrease in the level of the hormone causes stress, then the whole body starts to function at the level of healthier with more energy for healing (healing), reinforcement (restoration), and rejuvenation (rejuvenation).

Combination therapy progressive muscle relaxation and deep breathing relaxation is one of the stress management where it is expected that after doing this exercise stress experienced by the respondents can be decreased. Sigurdardottir (2005) in Maghfirah (2015) revealed that the emotional problems that are usually experienced by diabetes that is stress, sadness, a sense of worry about the future, think of the long term complications will probably show up, feeling the fear of living with DM, feel the spirit of the program of 
treatment that must be followed, worried to changes in blood sugar levels and get bored with routine maintenance should be undertaken. It is when not immediately followed will make the stressful conditions experienced by diabetes will be increasingly severe. Stress levels measured in this study is the stress associated with DM disease suffered. The stress caused due to other factors not measured and controlled in this study that there is a possibility of affecting the results.

Based on the results of research that has been done, then it can be drawn a conclusion that there is the influence of combination therapy progressive muscle relaxation and deep breath against the stress levels of diabetics in Prolanis BPJS Kesehatan Kota Palangka Raya.

\section{CONCLUSION}

a. The results of the statistical test using the test dependent sample t-Test (Paired t-Test) showed that there are differences in the average level of stress diabetes before and after the intervention, i.e., before the intervention is 2,57 and after the intervention is 2.10 . It shows that the level of stress diabetes after therapy is given progressive muscle relaxation and breath in decreased significantly by 0.47 with $p$ value $=0,000$ ( $\alpha$ $0,05)$. Based on the results of a statistical test, it can be concluded that at $\alpha 5 \%$ there were significant differences in the average level of stress diabetes before and after a given intervention in the form of therapy progressive muscle relaxation and deep breathing relaxation ( $p$ value $0.000<\alpha 0,005$ ).

b. Therapy progressive muscle relaxation and deep breathing relaxation given proven to reduce stress levels diabetes in Prolanis BPJS Kesehatan Kota Palangka Raya.

\section{REFERENCE}

[1] Aditama. 2011.Prevalensi diabetes diprediksi dua kali lipat pada 2030, [Online], Antara News, dari:

http://www.antaranews.com/berita/307183/prevalensi-diabetes-diprediksi-dua-kali-lipat. [10 Maret 2018]

[2] Balitbangkes. 2008.Riset Kesehatan Dasar 2007, Laporan Nasional, Balitbangkes Depkes RI, Jakarta.

[3] Balitbangkes. 2008. Riset Kesehatan Dasar Kalimantan Tengah 2007, Laporan Nasional, Balitbangkes Depkes RI, Jakarta.

[4] Dahlan,S. 2011. Statistik untuk Kedokteran dan Kesehatan.Edisi V, Salemba Medika,Jakarta.

[5] Dinkes Kota Palangka Raya, Puskesmas Pahandut diakses dari http://www.dinkes.palangkaraya.go.id pada tanggal 14 Januari 2018

[6] Fitria Indriani, 2010,Konsep Stres dan Manajemen stres, diunduh dari http://www.stikestrimandirisakti.com pada tanggal 2 April 2018

[7] Hanif, A. R. 2012. Perbedaan Tingkat Stres Sebelum dan Sesudah Dilakukan DSME Pada Pasien Diabetes Melitus Tipe 2 di Wilayah Kerja Puskesmas Rambipuji Kabupaten Jember. Jember: PSIK UNEJ

[8] Hidayat. 2008.Metode Penelitian Keperawatan dan Teknik Analisis Data, Salemba Medika, Jakarta

[9] Hungu. 2007. Demografi Kesehatan Indonesia, Grasindo, Jakarta

[10] Ashari, Irwan. 2012.Prevalensi Diabetes Mellitus Tipe 2 dan Aterosklerosis. Diunduh dari http://www.dokterirga.com pada tanggal 20 Desember 2018

[11] Kementerian Kesehatan RI, 2012 Tahun 2030 Prevalensi Diabetes Melitus Di Indonesia Mencapai 21,3 Juta Orang, diunduh dari http://www.depkes.go.id pada tanggal 20 Desember 2018

[12] Jamaluddin, Muhammad. 2007, Skripsi Penelitian : Strategi Coping Stres Penderita diabetes dengan self monitoring sebagai variable Mediasi, UIN Malang diakses 20 Juni 2018.

[13] Notoadmojo, S.2010.Ilmu Kesehatan Masyarakat, Prinsip-Prinsip Dasar, Rineka Cipta, Jakarta.

[14] Nursalam. 2003. Konsep \& Penerapan Metodologi Penelitian Ilmu Keperawatan, Salemba Medika, Jakarta.

[15] Perkeni.2006. Konsensus Pengelolaan dan Pencegahan Diabetes Melitus Tipe-2 di Indonesia,PERKENI, Jakarta.

[16] 2009. Buku panduan pengeloaan dan pencegahan prediabetes.PERKENI, Jakarta.

[17] Polonsky, W.H., et al. 2005. Assessing Psychosocial Distress in Diabetes. Diabetes Care [Serial onLine]. http://care.diabetesjournals.org/content/28/23/26.long. Diakses pada 14 Maret 2018.

[17] Putri YollaDwi Meydani.2011.Faktor-Faktor Yang Berhubungan Dengan Upaya Pencegahan Komplikasi DM Oleh Pasien DM Di Poliklinik Khusus Penyakit Dalam RSUP Dr M.Djamil Padang. Skripsi.FK Universitas Andalas. 
[18] Resti, I. B. 2014. Teknik Relaksasi Otot Progresif untuk Mengurangi Stres pada Penderita Asma. Jurnal Ilmiah Psikologi Terapan, 2 (1) : 1-20.

[19] Rudijanto, A. 2010.Pencegahan dan Penatalaksanaan Diabetes Melitus melalui Pendekatan Komunitas dalam pidato pengukuhan Jabatan Guru Besar dalam Ilmu Penyakit Dalam - Endokrin pada FK Unibraw. Malang.

[20] Rusanti, Putri. 2011. Hubungan Antara Tingkat Pengetahuan dengan Manajemen Stres pada Penderita Diabetes Melitus. Skripsi. Semarang: Universitas Muhammadiyah Semarang.

[21] Setyoadi, Kushariyadi. Terapi modalitas keperawatan pada klien psikogeriatrik. Salemba Medika. Jakarta; 2011

[22] Sri Idaiani,2010, Analisis Gejala Gangguan Mental Emosional Penduduk Indonesia, diakses dari http://www.indonesia.digitaljurnal.org pada tanggal 17 Desember 2018

[23] Soegondo,dkk. 2009. Penatalaksana DiabetesMelitusTerpadu. Edisikedua, Balai Penerbit FKUI, Jakarta.

[24] Sudoyo, dkk. 2006.Buku Ajar Ilmu Penyakit Dalam.Edisi Keempat, PusatPenerbit FKUI, Jakarta.

[25] Sulistyoningsih,H. 2011.Gizi untuk Kesehatan Ibu dan Anak.Edisi pertama, Graha Ilmu, Yogyakarta.

[26] Susilo. 2011. Cara Jitumengatasi diabetes melitus (kencing manis), ANDI, Jakarta.

[27] Tjokroprawiro, A. 2006.Hidup Sehat dan Bahagia Bersama Diabetes Melitus.edisi 2006, Gramedia Pustaka Utama, Jakarta.

[28] Varvolgi \& Darviri. 2011. Stress Management Techniques: Evidence-Based Procedures That Reduce Stress And Promote Health. Health and Science Journal, 5 (2) : 74-89.

[29] WHO. 2008. Global Prevalence of Diabetes, dari http://www.who.int/diabetes/facts/en/diabcare0504.pdf [2 Maret 2018]

[30] Wulandari, P. Y. 2006. Efektivitas Senam Hamil sebagai Pelayanan Pre Natal dalam Menurunkan Kecemasan Menghadapi Persalinan Pertama. Fakultas Psikologi Universitas Airlangga Surabaya 